place, the adult Mallard attempted to protect her young from the loon's attack by rushing towards it and flapping her wings. However, her efforts were in vain as it was evident she was much smaller than the loon.

The first three ducklings did not reappear after going under. However, the last one, which had been the first in the line of escape, rose to the surface inverted, its feet frantically fanning the air until eventually no motion was evident. The loon remained close to the scene while another loon joined it. Both loons floated casually in the area while preening themselves as the dead young bird floated on the surface 2-3 feet away. The female Mallard made several passes as if in search of her young, eventually giving up and moving off to another part of the lake. There were no signs of young loons with the adults and there was no evidence to indicate that the loons had fed on the dead birds. Upon our departure the loons remained in the area of the attack.
There are other instances of $\mathrm{ld}_{\mathrm{s}}$ killing birds. In Europe, Common LC s were seen eating young Commor i. ders. ${ }^{1}$ In New Hampshire, a grou if unmated loons attacked and killed o loon chicks. ${ }^{2}$ Candace Savage rep s that the Common Loon diet, in additic o fish, also "includes crustaceans, amp ians, and, occasionally, the young of $c *$ water birds." 3 In the Northwest Tel )ries, an Arctic Loon had a furious " with a Canada Goose defending its $n$ : The full length of the loon's bill ent $d$ the goose, puncturing its lung, and $k$ it.

'JONES, R. N. and M. OBBARD. Canada Goose killed by Arctic Loon ic subsequent pairing of its mate. Auk 870 371.

${ }^{2}$ KLEIN, TOM. 1985. Loon magic. F er Birch Press, Ashland, WI. 145 pp.

${ }^{3}$ SAVAGE, CANDACE. 1985. The won of Canadian birds. Western Producer $P$ ie Books, Saskatoon, SK. 211 pp.

\title{
WINTERING HORNED LARKS IN SOUTH SASKATCHEWAN
}

MARTIN BAILEY, 3634 McCallum Avenue, Regina, Saskatchewan. S4S 0SE

The Big Muddy Christmas Bird Count was first undertaken in 1988; the Bromhead count is now in its 3rd year. While the topography of the two circles is different, the centers of these counts are less than $100 \mathrm{~km}$ from each other, and both are less than $30 \mathrm{~km}$ north of the 49th parallel.

The 1988 counts occurred on 28 December for Bromhead; and $29 \mathrm{De}$ cember in the Big Muddy circle. The weather in both areas was esser lly the same. Both days were sunny ith little cloud. Temperatures ranger ie. tween $-20^{\circ}$ and $-15^{\circ} \mathrm{C}$ under light nd conditions.

Golden Eagles, Snowy Owls, ay Partridges and Ring-necked Phea its were observed in both areas. $S$ ip. tailed Grouse were conspicuous by eir absence at both sites. 
